\title{
第79回(平成21年)マリンエンジニアリング学術講演会 見学会
}

報告

Report

「株式会社シンコー」見学会後記*

吉田肇*

\section{1.はじめに}

第 79 回(平成 21 年)マリンエンジニアリング学術講 演会最終日の 9 月 18 日 (金), 見学会として株式会社シ ンコーを訪問させていただいた，その概要について， 以下，報告する.

\section{2. 会社説明および講演会}

学術講演会最終日, 午後, 会場のメルパルク広島か ら広島駅近くのシンコー本社へバスで移動した.まず, 本社会議室において，筒井会長からシンコーの沿革と 現状, そして今後についてご説明をいただいた.

シンコーは，昭和 13 年 12 月，株式会社新興金属工 業所の商号のもとに創業し, 主として船舶用ポンプ・ タービンを製造してきたが，オイルショックを機に陸 上方面にも進出し, 現在は, 陸·舶用ポンプ・タービン, 特に省エネ用発電機タービン, LNG および LPG ポンプ の製作とその市場開発等に力を注いでいる。昭和 63 年末の創業 50 周年を機に, CI 計画の基本のもとに社 名を株式会社シンコーに変更した.

筒井会長には，戦後の動乱期から，社員が常に一丸 となって未知の技術・経営分野へ挑戦してきたことに ついて，回想を交えてお話いただき，見学者一同，現 在の「技術と革新のシンコー」への道程に，感銘を改た にした.

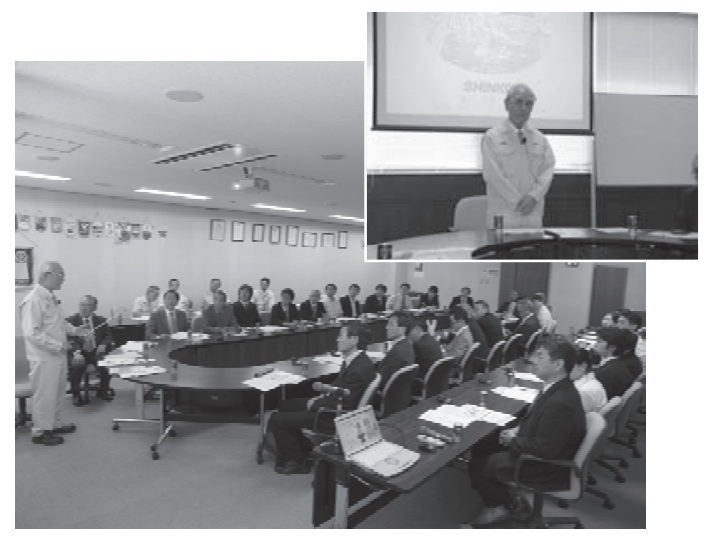

図 1 筒井会長による会社概要等の説明

*原稿受付 平成 21 年 10 月 14 日。

**正会員 海上保安大学校 (吳市若葉町5-1).
引き続き技術講演会を開催していただき，技術本部 平尾相談役から「Special Pipe と PERACLEAN ${ }^{\triangleright}$ Ocean によるバラスト水処理装置」という演題でご講演をい ただいた。 バラスト水とともに有害微生物が各国間を 移動し，養殖海産物への被害や，発電所タービン冷却 水取水口閉塞などの被害が報告されるに至り，バラス 卜水処理技術の開発とその船舶一の適用が不可欠とな った. バラスト水処理装置の船舶一の装備を義務付け た IMO 条約の批准も各国で進んでおり，シンコーは日 本におけるバラスト水処理装置開発態勢の一翼を担っ ている. シンコーの開発した処理装置の微生物殺滅の 原理は，薬剤と物理的殺滅を組み合わせたハイブリッ ド方式で，物理的殺滅のメカニズムにシンコーが培つ てきたポンプに関する多くの技術が生かされている. この方式は，薬剤のみを使用する方式と比較してその 使用量が約 $1 / 2$ となり, 環境にやさしく, また, 経済 面でも非常に優れたものである.

ご講演では船舶への設置および制御方法, 薬剤の供 給方法等についても解説いただき,また, ご講演後は出 席者からの活発な質疑に対し，予定を大きく超えてま で応答，説明に時間を割いていただいた。

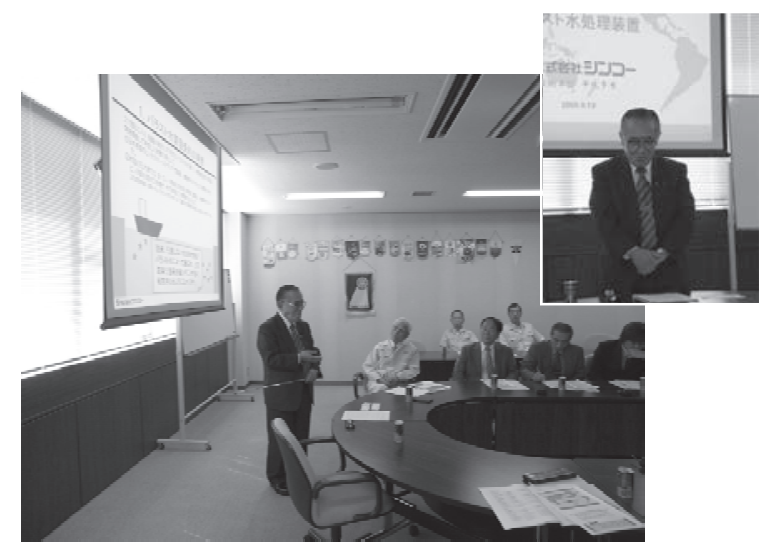

図 2 平尾相談役による技術講演

\section{3. 工場見学}

本社での会社説明および講演会終了後, 蒸気タービ ン製造工場，鋳造工場およびポンプ工場を見学させて いただいた．鋳造工場では多数の鋳型等の管理を自動 
化された管理システムにより行うなど，いずれの工場 でも集約されたスペースで効率よく生産が行われてお り, どの生産現場も活気に満ちていた.

また，シンコーのベンチャー精神の象徵のひとつと もいえる LNG ポンプ等の試験設備や，環境に配慮する 社風を具現化したものともいえる廃材を利用した自家 発電設備なども併せて見学させていただいた.
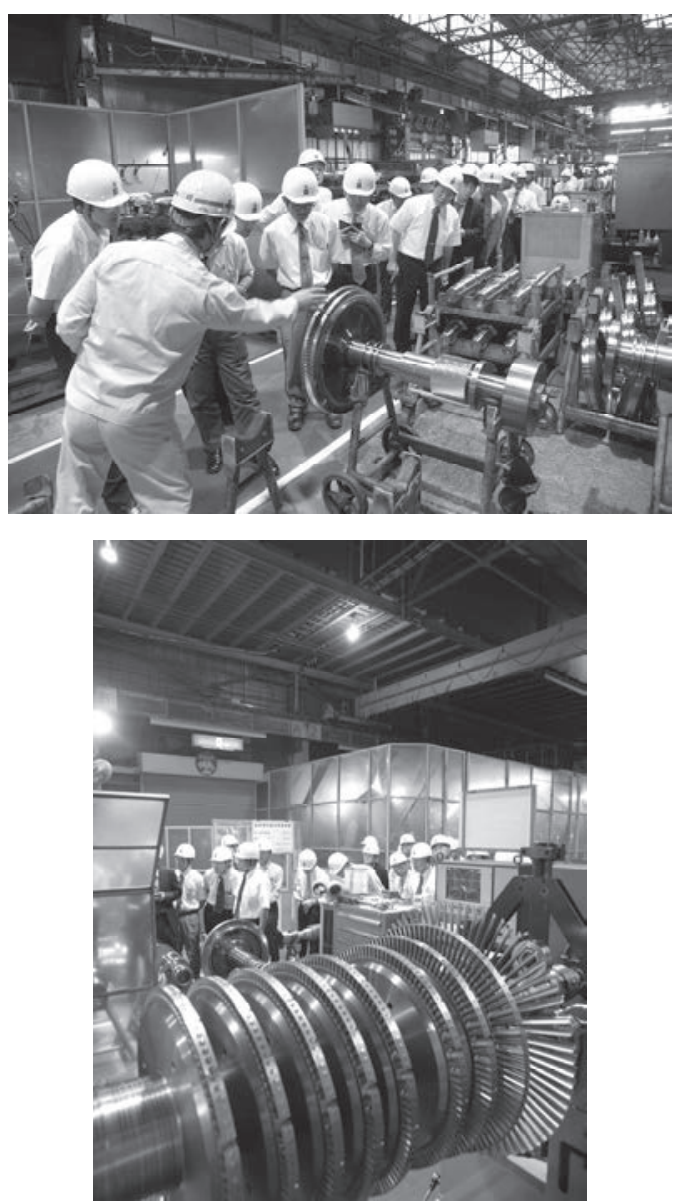

図 3 タービン工場見学

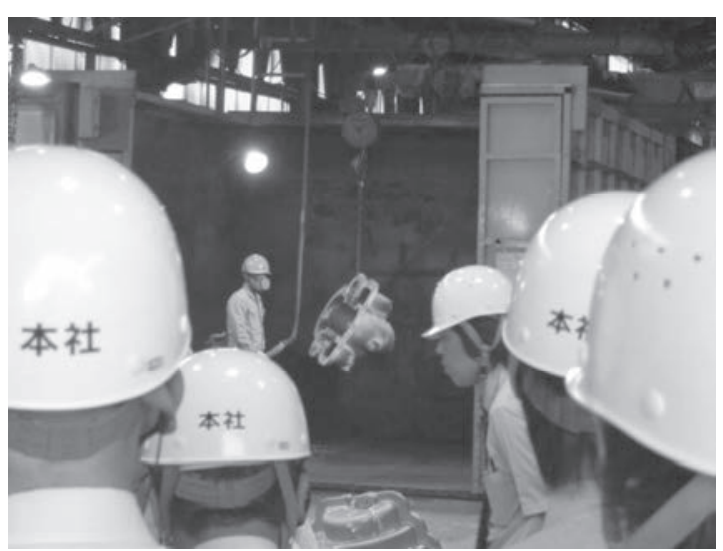

図 4 鋳造工場見学

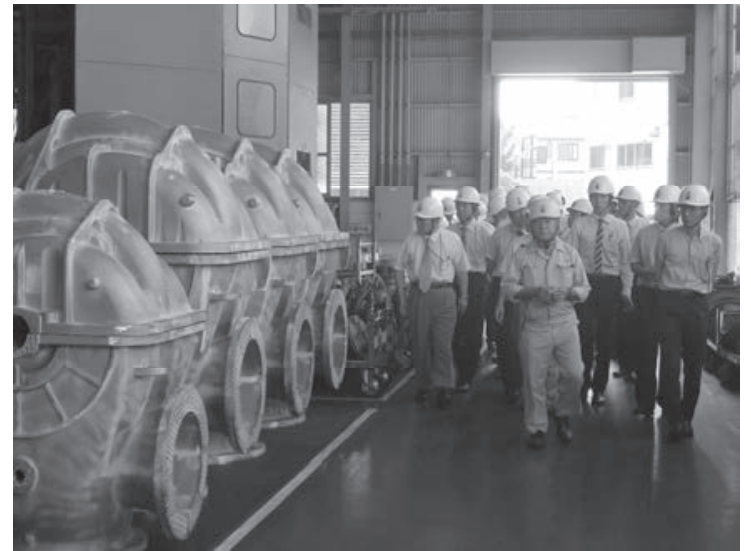

図 5 ポンプ工場見学

\section{4. おわりに}

工場見学終了後, 再び本社会議室にもどり, 黒木専 務，平尾相談役ほか社員の方々ご同席のもとでの質疑 応答で見学会を締めていただいた，会長のお話，平尾 相談役の講演会そして工場見学と, 密度の高いこの見 学会に見学者一同多くのものを得ることができ，心よ り感謝し, 記念撮影の後, シンコー本社を後にした.

本見学会の実施に当たり，お忙しい中，貴重な時間 を割いてご対応下さった方々,また, 企画段階から種々 ご相談に乗っていただき，見学会の実現にご尽力いた だいた方々をはじめとする株式会社シンコーの皆様に, 紙面をお借りして，ここに心よりお礼申し上げます。 ありがとうございました。

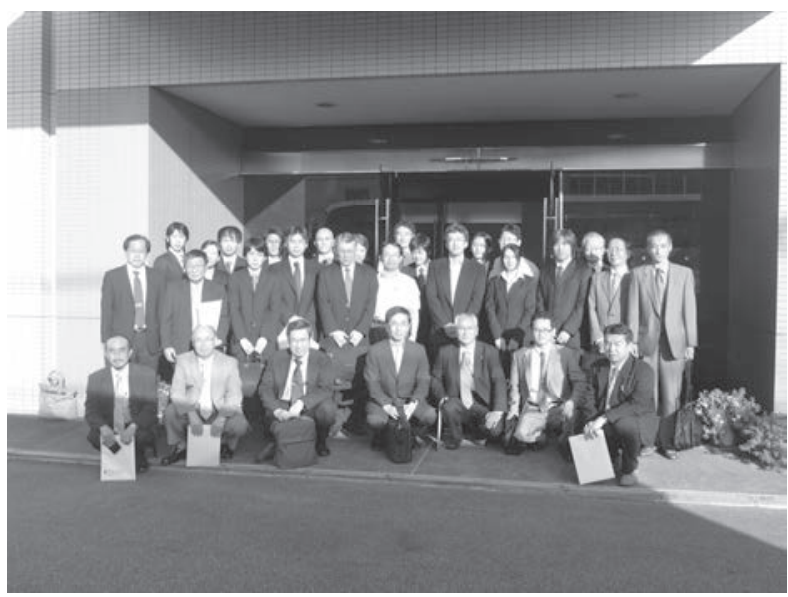

図 6 シンコー本社前にて 